OPEN ACCESS

Edited by:

Séamus Hussey,

National Children's Research Centre

(NCRC), Ireland

Reviewed by:

Sina Bartfeld,

Julius Maximilian University of

Würzburg, Germany

Aleixo Muise

University of Toronto, Canada

${ }^{*}$ Correspondence:

Lauren O'Connell laurenoconnel/@rcsi.ie

Specialty section

This article was submitted to Pediatric Gastroenterology,

Hepatology and Nutrition,

a section of the journal

Frontiers in Pediatrics

Received: 30 October 2020 Accepted: 18 January 2021

Published: 17 February 2021

Citation:

O'Connell L, Winter DC and Aherne CM (2021) The Role of Organoids as a Novel Platform for Modeling of Inflammatory Bowel Disease. Front. Pediatr. 9:624045. doi: 10.3389/fped.2021.624045

\section{The Role of Organoids as a Novel Platform for Modeling of Inflammatory Bowel Disease}

\author{
Lauren O'Connell ${ }^{1,2 *}$, Des C. Winter ${ }^{2}$ and Carol M. Aherne ${ }^{1}$ \\ ${ }^{1}$ Conway Institute of Biomolecular and Biomedical Research, School of Medicine, University College Dublin, Dublin, Ireland, \\ ${ }^{2}$ Centre for Colorectal Disease, St. Vincents' University Hospital, Dublin, Ireland
}

Inflammatory bowel disease (IBD) is a chronic relapsing-remitting immune-mediated disorder affecting the gut. It is common in Westernized regions and is increasing in incidence in developing countries. At a molecular level, intrinsic deficiencies in epithelial integrity, mucosal barrier function, and mechanisms of immune response and resolution contribute to the development of IBD. Traditionally two platforms have been utilized for disease modeling of IBD; in-vitro monolayer cell culture and in-vivo animal models. Both models have limitations, including cost, lack of representative cell types, lack of complexity of cellular interactions in a living organism, and xenogeneity. Organoids, three-dimensional cellular structures which recapitulate the basic architecture and functional processes of the organ of origin, hold potential as a third platform with which to investigate the pathogenesis and molecular defects which give rise to IBD. Organoids retain the genetic and transcriptomic profile of the tissue of origin over time and unlike monolayer cell culture can be induced to differentiate into most adult intestinal cell types. They may be used to model intestinal host-microbe interactions occurring at the mucosal barrier, are amenable to genetic manipulation and can be co-cultured with other cell lines of interest. Bioengineering approaches may be applied to render a more faithful representation of the intestinal epithelial niche. In this review, we outline the concept of intestinal organoids, discuss the advantages and disadvantages of the platform comparative to alternative models, and describe the translational applications of organoids in IBD.

Keywords: organoids, inflammatory bowel disease, disease modeling, mucosal defense, epithelial barrier

\section{INTRODUCTION}

Inflammatory bowel disease (IBD) is an immune-mediated relapsing-remitting chronic disorder affecting the gut. Alterations in the intestinal microbiome, defects in mucosal barrier defense and aberrant innate and adaptive immune responses appear to be critical to the development of IBD (1-7). Clinically, two major phenotypes exist, Crohn's disease (CD) and ulcerative colitis (UC). $\mathrm{CD}$ features transmural inflammation in a "skip lesion" or discontinuous pattern. Although it may affect any part of the gut the terminal ileum is most frequently involved $(1,2,8-10)$. UC affects the colon only, although a reactive "backwash ileitis" may occur. Inflammation is limited to the mucosa and submucosa and occurs in a continuous pattern, with rectal involvement extending proximally for a variable distance. Crypt abscesses due to accumulation of neutrophils are characteristic $(5,6,11)$. 


\section{PATHOGENESIS}

The underlying mechanisms which contribute to the etiology of IBD are highly complex and not yet fully elucidated. Genetic susceptibility, environmental factors, defects in mucosal barrier function, immune dysregulation, and dysbiosis have all been demonstrated to contribute to disease pathogenesis (12-18). Activation and recruitment of CD4+ $\mathrm{T}$ cells to the intestinal tissue and production of a proinflammatory cytokine cascade, particularly the Th1- and Th17-associated cytokines TNF $\alpha$, IFN $\gamma$, IL-12, IL-21, and IL-23 in CD and Th2-associated cytokines IL-4 and IL-13 in UC are commonly observed (5, 19-21).

Loss of a functional epithelial barrier and increased permeability of the mucus gel layer, permits abnormal contact of luminal organisms with the epithelium, provoking an inflammatory response from the immune system located in the lamina propria $(14,22-25)$. Failure of inflammation to resolve along with lack of restoration of normal mucosal homeostasis results in progression to chronic inflammation, inadequate epithelial restitution, and ongoing tissue damage (26). This is accompanied by characteristic disturbances in the composition of the gut microbiome, with a reduction of obligate anaerobes such as Firmicutes, an increase in facultative anaerobes such as Enterobacteriaceae and the presence of invasive strains such as adherent-invasive E.coli (AIEC) (27-30).

Genome-wide association studies have thus far identified up to 250 susceptibility loci involved in IBD. The most well-known of these is the Crohn's susceptibility locus CARD15, formerly known as NOD2, which is responsible for sensing of luminal bacterial organisms; others include IL23R and ATG16L1, which play roles in IL23 signaling and autophagy, respectively $(13,31,32)$. Many susceptibility loci are genes coding for components of the mucosal barrier. These include proteins responsible for assembly and maintenance of epithelial tight junctions, intercellular adhesion and polarity, mucin and glycoprotein synthesis, bacterial sensing mechanisms, and epithelial wound healing and restitution $(13,33,34)$.

Current therapeutic strategies in IBD primarily function by modification of the immune response. Biologic therapies targeting the cytokines TNF $\alpha$, IL-12 and IL-23, and integrin blockers which limit the migration of leukocytes to the GI tract have greatly expanded the repertoire of treatment options (35-37). However, up to $40 \%$ of patients fail to respond to biologic therapies, and up to $50 \%$ develop secondary treatment failure after an initial successful response (38). Although impaired barrier function is also a critical event in initiation and perpetuation of IBD no therapies directed at augmenting the barrier deficiency which occurs in IBD have successfully been developed for clinical practice. Due to the phenomenon of treatment-resistant IBD in a substantial proportion of patients, alternative strategies aimed at improving intestinal barrier function are warranted. Development of such therapies requires highly faithful modeling of the intestinal barrier in the preclinical setting.

\section{CURRENT MODELS OF IBD}

Traditional models for IBD comprise animal models and monolayer cell culture. Some animal models used to study IBD such as DSS-colitis and TNSB-colitis are extensively utilized and well-described $(39,40)$. In addition to chemically induced colitis, the creation of transgenic and knockout animal strains permit investigation of inflammation arising from specific defects in innate and adaptive immune responses (41-44). These models have the benefit of replicating the complex organization and simultaneous interactions that occur in the gut in a whole organism. Such models have been indispensable in unraveling the complex pathophysiology and molecular abnormalities that occur in IBD.

However, in-vivo disease modeling in animals does have some limitations. Chemical induction of colitis occurs by a heterogeneous mechanism to that by which inflammation occurs in human disease. While cell culture can be rapidly established, the length of animal reproductive cycles means that animal experiments are a slower process. Ethical considerations exist with the use of higher vertebrates which do not apply to cell culture. In addition, while the host-microbial interactions and inflammatory processes that occur in animal models are broadly applicable to humans, particular aspects of the microbiome, inflammatory response, and mucosal defense may be speciesspecific (45-47). Finally, animal models are poorly predictive of drug response and toxicity in humans $(48,49)$.

In-vitro immortalized intestinal human cell lines such as Caco-2, T84, and HT-29 cultures are excellent for investigating specific molecular interactions and signaling pathways under highly controlled conditions. They are derived from human tissue, are low-cost and can be rapidly established. However, monolayer cultures are reductive as a model and cannot replicate the complex interactions that occur in-vivo.

\section{ORGANOIDS}

Organoids are defined as 3-D structures derived from either pluripotent (embryonic or induced pluripotent), or adult tissueresident stem cells, which spontaneously self-organize and undergo a degree of differentiation, producing functional cell types, and which have the capacity to undertake some functions of the relevant organ (50).

While systems for maintaining intestinal tissue explants exvivo had been described since 1992, $(51,52)$ it was Eiraku et al. (53) and Sato et al. (54), respectively, who first successfully developed a method of producing the stem-cell derived, constructs known today as organoids. Studies by Sato et al. derived these from Lgr5+ adult stem cells (ASCs), first from murine and subsequently human intestinal crypts. They self-organized into crypt-villus type architecture and had the potential to produce most mature cell lines of the gut (5458). Since then organoid cultures have been successfully derived from other anatomical locations, including colonic, gastric and esophageal tissue $(55,56,59-62)$.

Organoids derived from small bowel tissue are sometimes referred to as enteroids or simply small bowel organoids, while 
organoids derived from colonic tissue may similarly be referred to as colonoids. They can be expanded from small volumes of tissue, including from endoscopic biopsies. Lgr $5^{+}$ASCs can be induced to differentiate into organoids containing all cell lines propagated by the gut, including mature enterocytes, Paneth cells, goblet cells, enteroendocrine, and tuft cells $(48,54,55,63)$. PSC-derived organoids can additionally generate adjacent stromal cell types. They recapitulate the spatial organization and polarity observed in the intestinal mucosa. Gut organoids are also capable of many of the functions of the source tissue, including endocrine and paracrine secretion, filtration, molecular transport, absorption, and contraction (48).

By contrast, while cheap and rapidly established, immortalized monolayer cell lines cannot recapitulate the complex cell-cell interactions or interactions with the extracellular microenvironment which occur in whole organisms $(64,65)$. Typically only single cell types are represented (66). It is not possible to culture rarer intestinal cell types such as tuft cells, and it can be difficult to acquire immortalized cell lines which secrete mucus to mimic the mucosal barrier which exists in-vivo $(48,61)$. Further, as monolayer cell cultures are derived from malignant cells they intrinsically demonstrate different properties to those of non-malignant cells, particularly with respect to epithelial integrity, cell polarity, and adhesion. These cells are not fully differentiated, and cell division in monolayer cell culture does not respond to the usual cellular signaling mechanisms which regulate this process in-vivo $(48,61,67)$ (Table $\mathbf{1})$.

Organoids theoretically have the potential to bridge the gap between monolayer cell culture and whole-organism environments. They are derived from human tissue and recapitulate the complex cellular organization seen in-vivo. However, they avoid the issues of xenogeneity which may be associated with animal models $(68,69)$. Organoids are also less costly and can be more rapidly established than animal models while retaining the potential for highly controlled molecular and genetic manipulation which is the salient attractive feature of monolayer cell culture (Table 1).

\section{TRANSLATIONAL APPLICATION OF ORGANOID MODELS IN IBD}

\section{Physiological Modeling of the Intestinal Niche}

Differential protein expression, gene expression, cell migration, organization, survival, and cell signaling have been observed in organoid cultures comparative to monolayer cell culture (70-73). Defects in the function of multiple epithelial cell types have been demonstrated in IBD, underlining the need for a physiologically relevant model which includes multiple cell lineages (74-78). Gut organoids may also be co-cultured with non-epithelial cell lines of interest in order to more accurately represent the intestinal mucosal niche. Co-culture of gut epithelial organoids with cell lines such as macrophages and lymphocytes and with mesenchymal cells demonstrate promise in providing a more physiologically relevant model of the gastrointestinal mucosal environment (79-82).
TABLE 1 | Characteristics of different modeling platforms in IBD.

\begin{tabular}{lccc}
\hline Feature & 2D cell & Animal \\
& culture & Organoids \\
& models & \\
\hline Cost & + & ++ & ++ \\
Culture cycle length & + & +++ & ++ \\
Presence of all intestinal cell types & - & ++ & ++ \\
Presence of non-epithelial elements & - & +++ & + - \\
of intestinal niche & & & ++ \\
Genetic stability & + & + & ++ \\
$\begin{array}{l}\text { Suitability for high-throughput } \\
\text { studies }\end{array}$ & ++ & & ++ \\
Suitability for drug toxicity screening & - & ++ & + \\
& & &
\end{tabular}

\section{Host-Microbe Interactions}

Due to this ability to accurately simulate the intestinal microenvironment, intestinal organoids represent exciting models for investigating the host-microbial interactions which are key to the pathogenesis of IBD. Organoids have already been successfully utilized as a more accurate model for human virus infection. In a study by Saxena, fully differentiated cells present in organoid culture supported greater rotavirus viral load and replication than had been previously observed in monolayer culture; and infection of enteroendocrine cell types in addition to enterocytes with rotavirus was demonstrated (83). Organoids have also been used to investigate norovirus, which is difficult to cultivate in monolayer cell culture. Previously only successfully cultured in B cells, organoids permitted culture of norovirus in duodenal, jejunal, and ileal cell types with viral replication and growth occurring within (84). Current applications of organoids include disease modeling of SARS-CoV-2 in respiratory and small intestinal derived cell types, with viral infection, replication, and host viral response observed ex-vivo (85-87).

Organoid cultures have also been applied to simulate hostbacterial interactions. Salmonella, H. pylori, C. difficile, and pathogenic $E$. coli infection have all been modeled in organoid cultures $(66,88-91)$. In one study, gastric organoids which secrete mucous, include multiple epithelial cell types and retain the polarity of the in-vivo gastric epithelium have been successfully utilized as a model for host-microbe interactions in H.pylori infection (66). Interestingly, duodenal, ileal and colonic organoid cultures derived from different donors demonstrate a differential response to infection and differing patterns of bacterial adhesion, possibly due to the genetic variability based on the tissue of origin (89). A co-culture model developed to study the host-pathogen interactions of $C$. jejuni incorporates intestinal enterocytes, mucin-secreting goblet cells and dendritic cells, thus combining a mucus-secreting epithelial layer with cellular elements of the intestinal innate immune system (92).

As well as modeling invasive microorganisms, organoids can also be used to study interactions between the gut and commensal microbiota. In one study, microbiota were found to play a role in epithelial regeneration in murine small bowel organoids. The pattern recognition receptor NOD2, single nucleotide polymorphisms (SNPs) of which are highly associated with Crohn's disease, is highly expressed in 
mouse intestinal stem cells (93-96). Stimulation of NOD2 by MDP (peptidoglycan muramyl-dipeptide), a bacterial cell wall constituent, enhanced organoid survival and protected them from oxidative-stress mediated cell death $(96,97)$. Organoids derived from adult and fetal murine tissues have also been utilized to determine developmental expression patterns of components of the innate immune system, including NOD2, TLR4, and TLR5 (98). Exposure of murine intestinal organoids to gut commensal bacteria including Akkermansia muciniphilia and Faecalibacterium prausnitzii has been shown to induce changes in gene expression and transcription, particularly of genes responsible for lipid metabolism (99). Similarly, exposure to the organism Bacteroides thetaiotaomicron and cytokine signaling via IL-22RA1 induces upregulation of Fut2 and increased fucosylation, which in turn inhibits colonization by opportunistic Enterococcus faecalis strains $(97,100,101)$. Finally, alterations in the microbiome have been associated with colonic neoplasia; colonic organoid models have been used to demonstrate a mutational profile induced by exposure to colibactin synthesized by genotoxic $E$. coli which is also associated with colorectal cancer in-vivo (102). Thus, organoid systems may be utilized to explore activity of the gut microbiome on the epithelium and mechanisms of homeostasis (Figure 1).

\section{Disease Modeling}

Unlike organoids derived from pluripotent stem cells, which rapidly accumulate mutations and epigenetic modifications, ASC-derived organoids are relatively genetically stable $(103,104)$. They retain the genetic profile and also the transcriptional and epigenetic landscape of the primary tissue from which they are derived $(73,105-107)$. While the majority of IBD is polygenic, some monogenic forms exist. These are mediated by specific genetic defects in epithelial dysfunction and stress response, defects in immune regulation of regulatory $\mathrm{T}$ cells or immunodeficiencies of phagocytic cells (108). Organoids represent useful models for studying these rare diseases, as well as other genetically determined intestinal disorders (109).

It is possible to culture intestinal organoids derived from patients with active IBD $(110,111)$. In one study, IBD colonic organoids demonstrated a distinct phenotype to those derived from control tissue, with a smaller size, increased cell death, abnormal cell polarization, and poorer budding capacity (110). Interestingly, they also expressed reduced quantities of the tight junction proteins ZO1, Occludin, and Claudin-1 as well as alterations in the expression of adherens junction and desmosomal proteins. These altered expression patterns persisted when the inflammatory stimulus was withdrawn (111). The phenotype and altered transcriptional profile noted in the IBD-derived organoids was inducible in the control organoids with administration of pro-inflammatory cytokines (TNF $\alpha$, IL1, and IL-6). Hibiya et al. demonstrated that murine colonic organoids which are exposed to chronic inflammatory stimuli (TNF $\alpha$, IL-1 $\beta$, IL-6, LPS, flagellin) underwent upregulation of the NFкB signaling pathway, which persisted after stimuli removal (112). These organoids also underwent transformation to an undifferentiated state, along with upregulation of genes related to oxidative stress and carcinogenesis (Smox and
CD151), suggesting their potential utility as a model to study the epithelial changes which occur in colitis-induced carcinogenesis. Vermeire et al. also generated $\mathrm{CD}$ and $\mathrm{UC}$ derived organoids which were subsequently exposed to TNF and flagellin, resulting in modulation of expression of the SARSCoV-2 receptor ACE2. These changes were restored to baseline with anti-TNF treatments (113). Other studies utilizing patientderived organoids from pediatric IBD patients demonstrated alterations in DNA methylation and transcriptional profiles, which correlated with treatment outcomes (114). Finally, a study by Jardine et al. successfully used colonic organoids generated from patients with TTC7A deficiency to perform high-throughput drug screening for candidate therapeutic agents (115). Loss of TTC7A causes intestinal epithelial apoptosis and immune defects which presents clinically as very early onset IBD. Thus, primary organoid cultures from inflamed tissue seem to represent an applicable model for investigation of the epithelial and mucosal abnormalities which occur in IBD (Figure 1).

\section{Bioengineering and Gut-on-a-Chip}

In the small intestine the mucosa of the gut is folded into villi and microvilli to maximize available surface area for absorption. Bioengineering techniques such as $3 \mathrm{D}$ printing and laser ablation allow the creation of scaffolds which recreate this intestinal topography. These can be directly seeded with epithelial organoids or used as molds to create hydrogel-based porous copies which reproduce the microanatomy of the gut (116). Alternatively, bioink comprising cell aggregates or organoids may be imprinted along with the desired biomaterials (hydrogels, matrix components) onto the scaffold via a computer-aided transfer process $(117,118)$. This allows for the creation of highly accurate and reproducible models with each componentorganoids, biomaterial, and scaffold-spatially aligned at the desired patterns, gradients, and densities set by the modeling software. Such methods will help to address both reproducibility and scaling-up of organoid cultures into larger tissue constructs. Some 3D gut models aimed at investigating the pathophysiology of inflammatory bowel disease are already in use (119).

Aside from gut anatomy, intestinal motility and luminal flow are physiologic functions of the gut which are difficult to mimic ex-vivo. These can be simulated via epithelial cell-lined microfluidic platforms, sometimes referred to as a "gut-on-achip" (120-122). Such platforms permit recapitulation of flow patterns, mechanical deformation, shear stresses, and peristaltic activity with greater accuracy than has been possible previously (117, 123-125). Organoid-lined laser-ablated microchips with active perfusion of media components have also been developed, which permit simulation of intestinal homeostasis and cell turnover with a reduced need for passaging (126). These platforms are being utilized to further investigate the gutmicrobiome relationship by inoculation with bacterial cultures and examining the effect of the physical environment on intestinal host-microbe interactions (127-132) (Figure 1).

\section{Regenerative Medicine}

The concept of mucosal healing as key to sustained remission of IBD has become increasingly prominent in recent years. This 


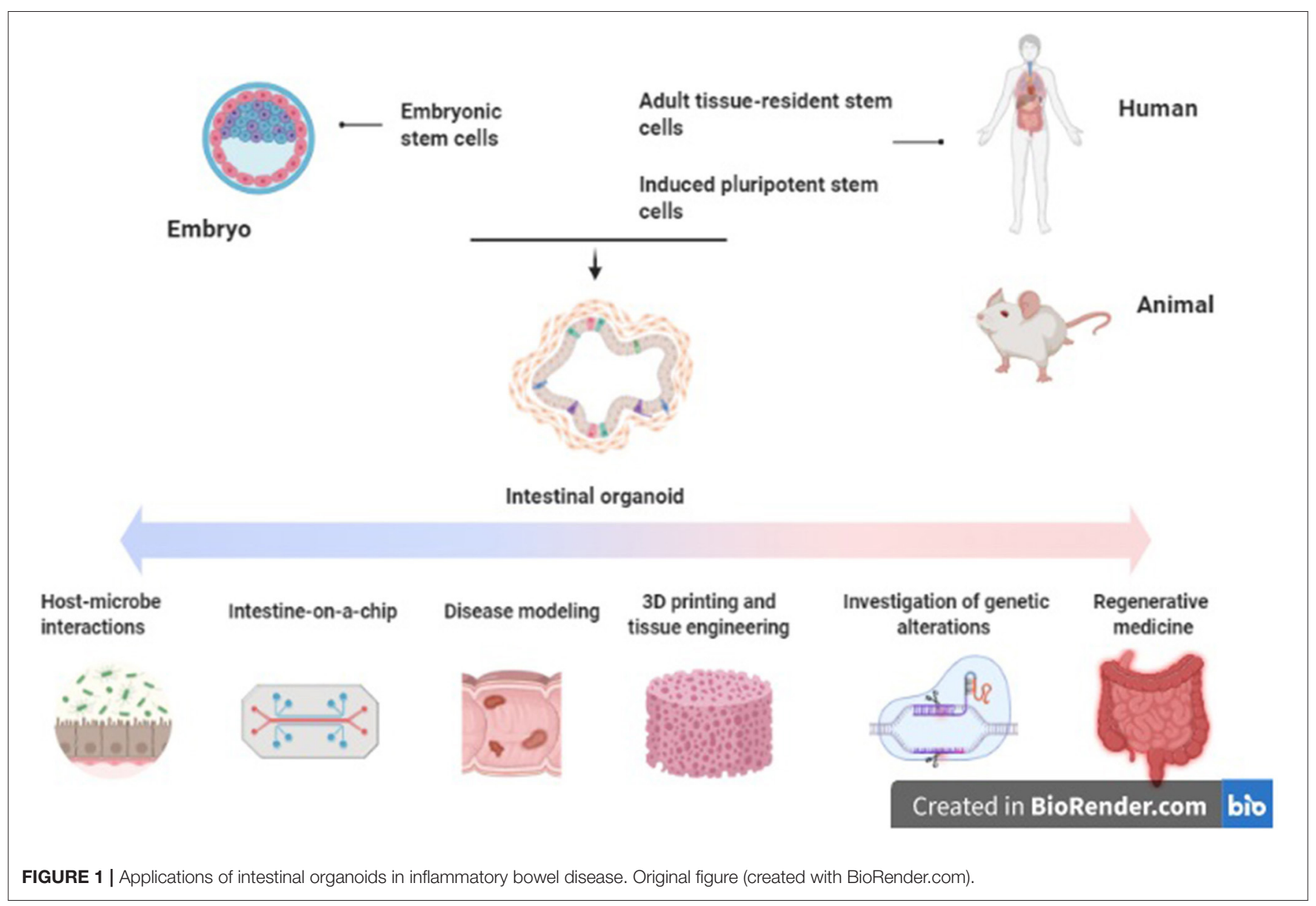

denotes absence of all mucosal ulceration at endoscopy, rather than resolution of clinical symptoms and serum biomarkers of inflammation alone $(133,134)$ Mucosal healing correlates with improved long-term clinical outcomes, including steroid use, hospital admissions and need for surgery in both CD and UC (135-139). The European Crohn's and Colitis Organization lists mucosal healing as a therapeutic target in its 2017 consensus guidelines for both UC and CD $(140,141)$. Local transplant of organoids to aid mucosal healing has been proposed as a potential therapy in IBD to aid epithelial regeneration and achieve mucosal healing (142). Studies using murine colitis models have demonstrated that human small bowel and colonic organoid cultures can engraft onto the ulcerated mucosa and reconstitute the normal crypt-villus architecture $(58,143,144)$. More recently, patient-derived small intestinal organoids have been successfully expanded ex-vivo and engrafted into mice, with the ultimate aim of creating autologous small intestinal transplants to treat intestinal failure (145) (Figure 1).

\section{Limitations of Organoids as a Model Platform}

Despite the advantages described above, there are limitations associated with the use of organoids. Comparative to twodimensional models they are more costly and less accessible, and require specialized medium to be maintained in culture. Matrigel and similar matrices in which they are typically cultured are expensive and increase the difficulty of manipulation. Particular studies such as transport and luminal exposure studies require injection of organoids which is a technically difficult and labor-intensive procedure; alternatives such as computer-assisted injection are again expensive and not readily available. Access to human tissue for generation of primary organoid cultures can be limited $(78,146)$. They are typically derived from epithelial tissues and so other components of the intestinal niche, including immune and mesenchymal elements, are underrepresented (146). As they are three-dimensional structures, this presents difficulty for investigations requiring access to the apical and basolateral surfaces. For this purpose they may be dissociated into 2D structures; however this disrupts their crypt-villus architecture and terminates their culture cycle (146). Finally, reproducibility of organoid cultures is challenging, as constructs of differing sizes and morphology result when they are grown in-vitro.

\section{CONCLUSION}

In summary, intestinal organoids represent a promising novel platform for further elucidating the host-microbe interactions, 
mucosal barrier deficiencies and genetic defects which underpin the pathogenesis of inflammatory bowel disease. Patient-derived organoids may have translational applications in the future as local therapy to aid mucosal healing. However, many limitations yet remain with this model. Some of these may be addressed by innovations such as computer-assisted bioprinting and $3 \mathrm{D}$ printed scaffolds to aid in reproducibility, and development of co-culture systems including immune and neuronal components to increase the physiological relevance of organoids as a platform for investigation of IBD.

\section{REFERENCES}

1. Baumgart DC, Sandborn WJ. Crohn's disease. Lancet. (2012) 380:1590-605. doi: 10.1016/S0140-6736(12)60026-9

2. Torres J, Mehandru S, Colombel J-F, Peyrin-Biroulet L. Crohn's disease. Lancet. (2017) 389:1741-55. doi: 10.1016/S0140-6736(16)31711-1

3. Ramos GP, Papadakis KA. Mechanisms of disease: inflammatory bowel diseases. Mayo Clin Proc. (2019) 94:155-65. doi: 10.1016/j.mayocp.2018.09.013

4. Khor B, Gardet A, Xavier RJ. Genetics and pathogenesis of inflammatory bowel disease. Nature. (2011) 474:307-17. doi: 10.1038/nature10209

5. Xavier RJ, Podolsky DK. Unravelling the pathogenesis of inflammatory bowel disease. Nature. (2007) 448:427-34. doi: 10.1038/nature06005

6. Ordás I, Eckmann L, Talamini M, Baumgart DC, Sandborn WJ. Ulcerative colitis. Lancet. (2012) 380:1606-19. doi: 10.1016/S0140-6736(12)60150-0

7. Ungaro R, Mehandru S, Allen PB, Peyrin-Biroulet L, Colombel J-F. Ulcerative colitis. Lancet. (2017) 389:1756-70. doi: 10.1016/S0140-6736(16)32126-2

8. DeFilippis EM, Longman R, Harbus M, Dannenberg K, Scherl EJ. Crohn's disease: evolution, epigenetics, and the emerging role of microbiome-targeted therapies. Curr Gastroenterol Rep. (2016) 18:13. doi: 10.1007/s11894-016-0487-z

9. Kotze PG, Shen B, Lightner A, Yamamoto T, Spinelli A, Ghosh S, et al. Modern management of perianal fistulas in Crohn's disease: future directions. Gut. (2018) 67:1181-94. doi: 10.1136/gutjnl-2017-314918

10. Gecse KB, Bemelman W, Kamm MA, Stoker J, Khanna R, Ng SC, et al. A global consensus on the classification, diagnosis and multidisciplinary treatment of perianal fistulising Crohn's disease. Gut. (2014) 63:1381-92. doi: 10.1136/gutjnl-2013-306709

11. Feuerstein JD, Cheifetz AS. Ulcerative colitis: epidemiology, diagnosis, and management. Mayo Clin Proc. (2014) 89:1553-63. doi: 10.1016/j.mayocp.2014.07.002

12. Zeissig S, Bürgel N, Günzel D, Richter J, Mankertz J, Wahnschaffe U, et al. Changes in expression and distribution of claudin 2, 5 and 8 lead to discontinuous tight junctions and barrier dysfunction in active Crohn's disease. Gut. (2007) 56:61-72. doi: 10.1136/gut.2006.094375

13. McCole DF. IBD candidate genes and intestinal barrier regulation. Inflamm Bowel Dis. (2014) 20:1829-49. doi: 10.1097/MIB.0000000000000090

14. Johansson MEV, Gustafsson JK, Holmén-Larsson J, Jabbar KS, Xia L, Xu H, et al. Bacteria penetrate the normally impenetrable inner colon mucus layer in both murine colitis models and patients with ulcerative colitis. Gut. (2014) 63:281-91. doi: 10.1136/gutjnl-2012-303207

15. Alipour M, Zaidi D, Valcheva R, Jovel J, Martínez I, Sergi C, et al. mucosal barrier depletion and loss of bacterial diversity are primary abnormalities in paediatric ulcerative colitis. J Crohns Colitis. (2016) 10:46271. doi: $10.1093 /$ ecco-jcc/jjv223

16. van der Post S, Jabbar KS, Birchenough G, Arike L, Akhtar N, Sjovall $\mathrm{H}$, et al. Structural weakening of the colonic mucus barrier is an early event in ulcerative colitis pathogenesis. Gut. (2019) 68:2142-51. doi: 10.1136/gutjnl-2018-317571

17. Jostins L, Ripke S, Weersma RK, Duerr RH. Host-microbe interactions have shaped the genetic architecture of inflammatory bowel disease. Nature. (2012) 491:119-24. doi: 10.1038/nature11582

\section{AUTHOR CONTRIBUTIONS}

LO'C: preparation of manuscript. DCW and CMA: concept, review and editing of manuscript, and approval prior to submission. All authors contributed to the article and approved the submitted version.

\section{FUNDING}

This work was supported by Crohn's and Colitis Foundation.

18. de Lange KM, Barrett JC. Understanding inflammatory bowel disease via immunogenetics. J Autoimmun. (2015) 64:91-100. doi: 10.1016/j.jaut.2015.07.013

19. Parkes M. Evidence from genetics for a role of autophagy and innate immunity in IBD pathogenesis. Dig Dis. (2012) 30:330-3. doi: $10.1159 / 000338119$

20. Geremia A, Biancheri P, Allan P, Corazza GR, Di Sabatino A. Innate and adaptive immunity in inflammatory bowel disease. Autoimmun Rev. (2014) 13:3-10. doi: 10.1016/j.autrev.2013.06.004

21. Xu X-R, Liu C-Q, Feng B-S, Liu Z-J. Dysregulation of mucosal immune response in pathogenesis of inflammatory bowel disease. World $J$ Gastroenterol. (2014) 20:3255-64. doi: 10.3748/wjg.v20.i12.3255

22. Lidar M, Langevitz P, Shoenfeld Y. The role of infection in inflammatory bowel disease: initiation, exacerbation and protection. Isr Med Assoc J. (2009) 11:558-63.

23. Michielan A, D'Incà R. Intestinal permeability in inflammatory bowel disease: pathogenesis, clinical evaluation, and therapy of leaky gut. Mediators Inflamm. (2015) 2015:628157. doi: 10.1155/2015/628157

24. Gerova VA, Stoynov SG, Katsarov DS, Svinarov DA. Increased intestinal permeability in inflammatory bowel diseases assessed by iohexol test. World J Gastroenterol. (2011) 17:2211-5. doi: 10.3748/wjg.v17.i17.2211

25. Swidsinski A, Loening-Baucke V, Theissig F, Engelhardt H, Bengmark S, Koch S, et al. Comparative study of the intestinal mucus barrier in normal and inflamed colon. Gut. (2007) 56:343-50. doi: 10.1136/gut.2006.098160

26. Rigottier-Gois L. Dysbiosis in inflammatory bowel diseases: the oxygen hypothesis. ISME J. (2013) 7:1256-61. doi: 10.1038/ismej.2013.80

27. Kaur N, Chen C-C, Luther J, Kao JY. Intestinal dysbiosis in inflammatory bowel disease. Gut Microbes. (2011) 2:211-6. doi: 10.4161/gmic.2.4.17863

28. Palmela C, Chevarin C, Xu Z, Torres J, Sevrin G, Hirten R, et al. Adherentinvasive Escherichia coli in inflammatory bowel disease. Gut. (2018) 67:57487. doi: 10.1136/gutjnl-2017-314903

29. Barnich N, Carvalho FA, Glasser A-L, Darcha C, Jantscheff P, Allez M, et al. CEACAM6 acts as a receptor for adherent-invasive E. coli, supporting ileal mucosa colonization in Crohn disease. J Clin Invest. (2007) 11:1566-74. doi: 10.1172/JCI30504

30. Dreux N, Denizot J, Martinez-Medina M, Mellmann A, Billig M, Kisiela D, et al. Point mutations in FimH adhesin of Crohn's disease-associated adherent-invasive Escherichia coli enhance intestinal inflammatory response. PLoS Pathog. (2013) 9:e1003141. doi: 10.1371/journal.ppat.1003141

31. Mizoguchi A. Animal models of inflammatory bowel disease. Prog Mol Biol Transl Sci. (2012) 105:263-320. doi: 10.1016/B978-0-12-394596-9.00009-3

32. Duerr RH. Update on the genetics of inflammatory bowel disease. J Clin Gastroenterol. (2003) 37:358-67. doi: 10.1097/00004836-200311000-00003

33. Hong M, Ye BD, Yang S-K, Jung S, Lee H-S, Kim BM, et al. Immunochip meta-analysis of inflammatory owel disease identifies three novel loci and four novel associations in previously reported loci. J Crohns Colitis. (2018) 12:730-41. doi: 10.1093/ecco-jcc/jjy002

34. de Lange KM, Moutsianas L, Lee JC, Lamb CA, Luo Y, Kennedy NA, et al. Genome-wide association study implicates immune activation of multiple integrin genes in inflammatory bowel disease. Nat Genet. (2017) 49:256-61. doi: $10.1038 /$ ng. 3760

35. Wong U, Cross RK. Expert opinion on interleukin-12/23 and interleukin23 antagonists as potential therapeutic options for the treatment of 
inflammatory bowel disease. Expert Opin Investig Drugs. (2019) 28:473-9. doi: 10.1080/13543784.2019.1597053

36. Verstockt B, Ferrante M, Vermeire S, Van Assche G. New treatment options for inflammatory bowel diseases. J Gastroenterol. (2018) 53:585-90. doi: 10.1007/s00535-018-1449-z

37. Danese S, Vuitton L, Peyrin-Biroulet L. Biologic agents for IBD: practical insights. Nat Rev Gastroenterol Hepatol. (2015) 12:537-45. doi: 10.1038/nrgastro.2015.135

38. Fine S, Papamichael K, Cheifetz AS. Etiology and management of lack or oss of Rresponse to anti-tumor necrosis factor therapy in patients with inflammatory bowel disease. Gastroenterol Hepatol. (2019) 15:656-65.

39. Chassaing B, Aitken JD, Malleshappa M, Vijay-Kumar M. Dextran sulfate sodium (DSS)-induced colitis in mice. Curr Protoc Immunol. (2014) 104:15.25.1-14. doi: 10.1002/0471142735.im1525s104

40. Neurath M, Fuss I, Strober W. TNBS-colitis. Int Rev Immunol. (2000) 19:51-62. doi: 10.3109/08830180009048389

41. Rothemich A, Arthur JC. The Azoxymethane/Il10 -/- model of colitisassociated cancer (CAC). Methods Mol Biol. (2019) 1960:215-25. doi: 10.1007/978-1-4939-9167-9_19

42. Liu X, Wei W, Li X, Shen P, Ju D, Wang Z, et al. BMI1 and MEL18 promote colitis-associated cancer in mice via REG3B and STAT3. Gastroenterology. (2017) 153:1607-20. doi: 10.1053/j.gastro.2017.07.044

43. Aherne CM, Collins CB, Masterson JC, Tizzano M, Boyle TA, Westrich JA, et al. Neuronal guidance molecule netrin-1 attenuates inflammatory cell trafficking during acute experimental colitis. Gut. (2012) 61:695-705. doi: 10.1136/gutjnl-2011-300012

44. van der Sluis M, Bouma J, Vincent A, Velcich A, Carraway KL, Büller $\mathrm{HA}$, et al. Combined defects in epithelial and immunoregulatory factors exacerbate the pathogenesis of inflammation: mucin 2-interleukin 10deficient mice. Lab Invest. (2008) 88:634-42. doi: 10.1038/labinvest.2008.28

45. Sollid LM, Johansen F-E. Animal models of inflammatory bowel disease at the dawn of the new genetics era. PLoS Med. (2008) 5:e198. doi: 10.1371/journal.pmed.0050198

46. Cerquetella M, Spaterna A, Laus F, Tesei B, Rossi G, Antonelli $\mathrm{E}$, et al. Inflammatory bowel disease in the dog: differences and similarities with humans. World J Gastroenterol. (2010) 16:1050-6. doi: 10.3748/wjg.v16.i9.1050

47. Jiminez JA, Uwiera TC, Douglas Inglis G, Uwiera RRE. Animal models to study acute and chronic intestinal inflammation in mammals. Gut Pathog. (2015) 7:29. doi: 10.1186/s13099-015-0076-y

48. George MM, Rahman M, Connors J, Stadnyk AW. Opinion: are organoids the end of model evolution for studying host intestinal epithelium/microbe interactions? Microorganisms. (2019) 7:406 doi: 10.3390/microorganisms7100406

49. Kamb A. What's wrong with our cancer models? Nat Rev Drug Discov. (2005) 4:161-5. doi: 10.1038/nrd1635

50. Lancaster MA, Knoblich JA. Organogenesis in a dish: modeling development and disease using organoid technologies. Science. (2014) 345:1247125. doi: $10.1126 /$ science. 1247125

51. Evans GS, Flint N, Somers AS, Eyden B, Potten CS. The development of a method for the preparation of rat intestinal epithelial cell primary cultures. $J$ Cell Sci. (1992) 101:219-31.

52. Fukamachi H. Proliferation and differentiation of fetal rat intestinal epithelial cells in primary serum-free culture. J Cell Sci. (1992) 103:511-9.

53. Eiraku M, Watanabe K, Matsuo-Takasaki M, Kawada M, Yonemura S, Matsumura M, et al. Self-organized formation of polarized cortical tissues from ESCs and its active manipulation by extrinsic signals. Cell Stem Cell. (2008) 3:519-32.

54. Sato T, Vries RG, Snippert HJ, van de Wetering M, Barker N, Stange $\mathrm{DE}$, et al. Single Lgr5 stem cells build crypt-villus structures in vitro without a mesenchymal niche. Nature. (2009) 459:262-5. doi: 10.1038/nature 07935

55. Múnera JO, Sundaram N, Rankin SA, Hill D, Watson C, Mahe M, et al. Differentiation of human pluripotent stem cells into colonic organoids via transient activation of BMP signaling. Cell Stem Cell. (2019) 24:829. doi: 10.1016/j.stem.2019.04.002

56. Sato T, Stange DE, Ferrante M, Vries RGJ, Van Es JH, Van den Brink $\mathrm{S}$, et al. Long-term expansion of epithelial organoids from human colon, adenoma, adenocarcinoma, and Barrett's epithelium. Gastroenterology. (2011) 141:1762-72. doi: 10.1053/j.gastro.2011.07.050

57. Spence JR, Mayhew CN, Rankin SA, Kuhar MF, Vallance JE, Tolle K, et al. Directed differentiation of human pluripotent stem cells into intestinal tissue in vitro. Nature. (2011) 470:105-9. doi: 10.1038/nature09691

58. Yui S, Nakamura T, Sato T, Nemoto Y, Mizutani T, Zheng X, et al. Functional engraftment of colon epithelium expanded in vitro from a single adult Lgr5+ stem cell. Nat Med. (2012) 18:618-23. doi: 10.1038/nm.2695

59. Seidlitz T, Merker SR, Rothe A, Zakrzewski F, von Neubeck C, Grützmann $\mathrm{K}$, et al. Human gastric cancer modelling using organoids. Gut. (2019) 68:207-17. doi: 10.1136/gutjnl-2017-314549

60. Li X, Francies H, Miremadi A, Grantham A, Grehan N, Devonshire G, et al. Su2042-derivation of oesophageal organoids to recapitulate the heterogeneity of primary umours and provide a model system for precision therapeutics. Gastroenterology. (2019) 156:S-696. doi: 10.1016/S0016-5085(19)38664-0

61. Dotti I, Salas A. Potential use of human stem cell-derived intestinal organoids to study inflammatory bowel diseases. Inflamm Bowel Dis. (2018) 24:2501-9. doi: $10.1093 /$ ibd/izy 275

62. Barker N, Huch M, Kujala P, van de Wetering M, Snippert HJ, van Es $\mathrm{JH}$, et al. Lgr5(+ve) stem cells drive self-renewal in the stomach and build long-lived gastric units in vitro. Cell Stem Cell. (2010) 6:25-36. doi: 10.1016/j.stem.2009.11.013

63. Lau W de, de Lau W, Kujala P, Schneeberger K, Middendorp S, Li VSW, et al. Peyer's patch $M$ cells derived from Lgr5 stem cellsrequire SpiB and are induced by RankL in cultured "Miniguts". Mol Cell Biol. (2012) 32:3639-47. doi: 10.1128/MCB.00434-12

64. O'Connell L, Winter DC. Organoids: past learning and future directions. Stem Cells Dev. (2020) 29:281-9. doi: 10.1089/scd.2019.0227

65. Gjorevski N, Sachs N, Manfrin A, Giger S, Bragina ME, Ordóñez-Morán P, et al. Designer matrices for intestinal stem cell and organoid culture. Nature. (2016) 539:560-4. doi: 10.1038/nature20168

66. Boccellato F, Woelffling S, Imai-Matsushima A, Sanchez G, Goosmann C, Schmid M, et al. Polarised epithelial monolayers of the gastric mucosa reveal insights into mucosal homeostasis and defence against infection. Gut. (2018) 68:400-13. doi: 10.1136/gutjnl-2017-314540

67. Snippert HJ, van der Flier LG, Sato T, van Es JH, van den Born M, Kroon-Veenboer C, et al. Intestinal crypt homeostasis results from neutral competition between symmetrically dividing Lgr5 stem cells. Cell. (2010) 143:134-44. doi: 10.1016/j.cell.2010.09.016

68. Takao K, Miyakawa T. Genomic responses in mouse models greatly mimic human inflammatory diseases. Proc Natl Acad Sci USA. (2015) 112:1167-72. doi: 10.1073/pnas.1401965111

69. Seok J, Warren HS, Cuenca AG, Mindrinos MN, Baker HV, Xu W, et al. Genomic responses in mouse models poorly mimic human inflammatory diseases. Proc Natl Acad Sci USA. (2013) 110:3507-12. doi: 10.1073/pnas.1222878110

70. Chen J, Williams S, Ho S, Loraine H, Hagan D, Whaley JM, et al. Quantitative PCR tissue expression profiling of the human SGLT2 gene and related family members. Diabetes Ther. (2010) 1:57-92. doi: 10.1007/s13300-0100006-4

71. Zietek T, Rath E, Haller D, Daniel H. Intestinal organoids for assessing nutrient transport, sensing and incretin secretion. Sci Rep. (2015) 5:16831. doi: $10.1038 /$ srep 16831

72. Pelagalli A, Squillacioti C, Mirabella N, Meli R. Aquaporins in health and disease: an overview focusing on the gut of different species. Int J Mol Sci. (2016) 179(1):02419-17. doi: 10.3390/ijms17081213

73. Middendorp S, Schneeberger K, Wiegerinck CL, Mokry M, Akkerman RDL, van Wijngaarden S, et al. Adult stem cells in the small intestine are intrinsically programmed with their location-specific function. Stem Cells. (2014) 32:1083-91. doi: 10.1002/stem.1655

74. Arijs I, De Hertogh G, Machiels K, Van Steen K, Lemaire K, Schraenen A, et al. Mucosal gene expression of cell adhesion molecules, chemokines, and chemokine receptors in patients with inflammatory bowel disease before and after infliximab treatment. Am J Gastroenterol. (2011) 106:748-61. doi: 10.1038/ajg.2011.27

75. Arijs I, De Hertogh G, Lemaire K, Quintens R. Mucosal gene expression of antimicrobial peptides in inflammatory bowel disease 
before and after first infliximab treatment. PLoS ONE. (2009) 4:e7984. doi: 10.1371/journal.pone.0007984

76. Surawicz CM, Haggitt RC, Husseman M, McFarland LV. Mucosal biopsy diagnosis of colitis: acute self-limited colitis and idiopathic inflammatory bowel disease. Gastroenterology. (1994) 107:755-63. doi: 10.1016/0016-5085(94)90124-4

77. Knowlton S, Onal S, Yu CH, Zhao JJ, Tasoglu S. Bioprinting for cancer research. Trends Biotechnol. (2015) 33:504-13. doi: 10.1016/j.tibtech.2015.06.007

78. Noben M, Vanhove W, Arnauts K, Santo Ramalho A, Van Assche G, Vermeire S, et al. Human intestinal epithelium in a dish: current models for research into gastrointestinal pathophysiology. United European Gastroenterol J. (2017) 5:1073-81. doi: 10.1177/2050640617722903

79. Nozaki K, Mochizuki W, Matsumoto Y, Matsumoto T, Fukuda M, Mizutani T, et al. Co-culture with intestinal epithelial organoids allows efficient expansion and motility analysis of intraepithelial lymphocytes. $J$ Gastroenterol. (2016) 51:206-13. doi: 10.1007/s00535-016-1170-8

80. Noel G, Baetz NW, Staab JF, Donowitz M, Kovbasnjuk O, Pasetti MF, et al. Erratum: a primary human macrophage-enteroid co-culture model to investigate mucosal gut physiology and host-pathogen interactions. Sci Rep. (2017) 7:46790. doi: 10.1038/srep46790

81. Pastuła A, Middelhoff M, Brandtner A, Tobiasch M, Höhl B, Nuber AH, et al. Three-dimensional gastrointestinal organoid culture in combination with nerves or fibroblasts: a method to characterize the gastrointestinal stem cell niche. Stem Cells Int. (2016) 2016:3710836. doi: 10.1155/2016/3710836

82. Workman MJ, Mahe MM, Trisno S, Poling HM, Watson CL, Sundaram $\mathrm{N}$, et al. Engineered human pluripotent-stem-cell-derived intestinal tissues with a functional enteric nervous system. Nat Med. (2017) 23:49-59. doi: $10.1038 / \mathrm{nm} .4233$

83. Saxena K, Blutt SE, Ettayebi K, Zeng X-L, Broughman JR, Crawford SE, et al. Human intestinal enteroids: a new model to study human rotavirus infection, host restriction, and pathophysiology. J Virol. (2016) 90:43-56. doi: 10.1128/JVI.01930-15

84. Ettayebi K, Crawford SE, Murakami K, Broughman JR, Karandikar U, Tenge $\mathrm{VR}$, et al. Replication of human noroviruses in stem cell-derived human enteroids. Science. (2016) 353:1387-93. doi: 10.1126/science.aaf5211

85. Lamers MM, van der Vaart J, Knoops K, Riesebosch S, Breugem TI, Mykytyn AZ, et al. An organoid-derived bronchioalveolar model for SARSCoV-2 infection of human Alveolar-type II-like cells. EMBO J. (2020). doi: 10.15252/embj.2020105912. [Epub ahead of print].

86. Lamers MM, Beumer J, van der Vaart J, Knoops K, Puschhof J, Breugem TI, et al. SARS-CoV-2 productively infects human gut enterocytes. Science. (2020) 369:50-4. doi: 10.1126/science.abc1669

87. Stanifer ML, Kee C, Cortese M, Zumaran CM, Triana S, Mukenhirn $\mathrm{M}$, et al. Critical role of type III interferon in controlling SARS-CoV-2 infection in human intestinal epithelial cells. Cell Rep. (2020) 32:107863. doi: 10.1016/j.celrep.2020.107863

88. Forbester JL, Goulding D, Vallier L, Hannan N, Hale C, Pickard D, et al. Interaction of salmonella enterica serovar typhimurium with intestinal organoids derived from human induced pluripotent stem cells. Infect Immun. (2015) 83:2926-34. doi: 10.1128/IAI.00161-15

89. Rajan A, Vela L, Zeng X-L, Yu X, Shroyer N, Blutt SE, et al. Novel segment- and host-specific patterns of enteroaggregative Escherichia coli adherence to human intestinal enteroids. mBio. (2018) 9:02419-17. doi: 10.1128/mBio.02419-17

90. Engevik MA, Engevik KA, Yacyshyn MB, Wang J, Hassett DJ, Darien B, et al. Human Clostridium difficile infection: inhibition of NHE3 and microbiota profile. Am J Physiol Gastrointest Liver Physiol. (2015) 308:G497509. doi: 10.1152/ajpgi.00090.2014

91. Leslie JL, Huang S, Opp JS, Nagy MS, Kobayashi M, Young VB, et al. Persistence and toxin production by Clostridium difficile within human intestinal organoids result in disruption of epithelial paracellular barrier function. Infect Immun. (2015) 83:138-45. doi: 10.1128/IAI.02561-14

92. Zamora CY, Ward EM, Kester JC, Chen WLK, Velazquez JG, Griffith LG, et al. Application of a gut-immune co-culture system for the study of $\mathrm{N}$-glycan-dependent host-pathogen interactions of Campylobacter jejuni. Glycobiology. (2020) 30:374-81. doi: 10.1093/glycob/cwz105
93. Adler J, Rangwalla SC, Dwamena BA, Higgins PDR. The prognostic power of the NOD2 genotype for complicated Crohn's disease: a meta-analysis. Am J Gastroenterol. (2011) 106:699-712. doi: 10.1038/ajg.2011.19

94. Chen Y, Salem M, Boyd M, Bornholdt J, Li Y, Coskun M, et al. Relation between NOD2 genotype and changes in innate signaling in Crohn's disease on mRNA and miRNA levels. NPJ Genom Med. (2017) 2:3. doi: 10.1038/s41525-016-0001-4

95. Glas J, Seiderer J, Tillack C, Pfennig S, Beigel F, Jürgens M, et al. The NOD2 single nucleotide polymorphisms rs2066843 and rs2076756 are novel and common Crohn's disease susceptibility gene variants. PLoS ONE. (2010) 5:e14466. doi: 10.1371/journal.pone.0014466

96. Nigro G, Rossi R, Commere P-H, Jay P, Sansonetti PJ. The cytosolic bacterial peptidoglycan sensor Nod2 affords stem cell protection and links microbes to gut epithelial regeneration. Cell Host Microbe. (2014) 15:792-8. doi: 10.1016/j.chom.2014.05.003

97. Dutta D, Heo I, Clevers H. Disease modeling in stem cellderived 3D organoid systems. Trends Mol Med. (2017) 23:393-410. doi: 10.1016/j.molmed.2017.02.007

98. Kayisoglu O, Weiss F, Niklas C, Pierotti I, Pompaiah M, Wallaschek N, et al. Location-specific cell identity rather than exposure to GI microbiota defines many innate immune signalling cascades in the gut epithelium. Gut. (2020). doi: 10.1136/gutjnl-2019-319919. [Epub ahead of print].

99. Lukovac S, Belzer C, Pellis L, Keijser BJ, de Vos WM, Montijn RC, et al. Differential modulation by Akkermansia muciniphila and Faecalibacterium prausnitzii of host peripheral lipid metabolism and histone acetylation in mouse gut organoids. MBio. (2014) 12:01438-14. doi: $10.1128 / \mathrm{mBio} .01438-14$

100. Engevik MA, Aihara E, Montrose MH, Shull GE, Hassett DJ, Worrell RT. Loss of NHE3 alters gut microbiota composition and influences Bacteroides thetaiotaomicron growth. Am J Physiol Gastrointest Liver Physiol. (2013) 305:G697-711. doi: 10.1152/ajpgi.00184.2013

101. Pham TAN, Clare S, Goulding D, Arasteh JM, Stares MD, Browne HP, et al. Epithelial IL-22RA1-mediated fucosylation promotes intestinal colonization resistance to an opportunistic pathogen. Cell Host Microbe. (2014) 16:50416. doi: 10.1016/j.chom.2014.08.017

102. Pleguezuelos-Manzano C, Puschhof J, Rosendahl Huber A, van Hoeck A, Wood HM, Nomburg J, et al. Mutational signature in colorectal cancer caused by genotoxic pks+ E. coli. Nature. (2020) 580:269-73. doi: 10.1038/s41586-020-2080-8

103. Behjati S, Huch M, van Boxtel R, Karthaus W, Wedge DC, Tamuri AU, et al. Genome sequencing of normal cells reveals developmental lineages and mutational processes. Nature. (2014) 513:422-5. doi: 10.1038/nature13448

104. Liang G, Zhang Y. Genetic and epigenetic variations in iPSCs: potential causes and implications for application. Cell Stem Cell. (2013) 13:149-59. doi: 10.1016/j.stem.2013.07.001

105. Cramer JM, Thompson T, Geskin A, LaFramboise W, Lagasse E. Distinct human stem cell populations in small and large intestine. PLoS ONE. (2015) 10:e0118792. doi: 10.1371/journal.pone.0118792

106. Kraiczy J, Nayak KM, Howell KJ, Ross A, Forbester J, Salvestrini C, et al. DNA methylation defines regional identity of human intestinal epithelial organoids and undergoes dynamic changes during development. Gut. (2019) 68:49-61. doi: 10.1136/gutjnl-2017-314817

107. Yoo J-H, Donowitz M. Intestinal enteroids/organoids: a novel platform for drug discovery in inflammatory bowel diseases. World J Gastroenterol. (2019) 25:4125-47. doi: 10.3748/wjg.v25.i30.4125

108. Uhlig HH. Monogenic diseases associated with intestinal inflammation: implications for the understanding of inflammatory bowel disease. Gut. (2013) 62:1795-805. doi: 10.1136/gutjnl-2012-303956

109. Bigorgne AE, Farin HF, Lemoine R, Mahlaoui N, Lambert N, Gil M, et al. TTC7A mutations disrupt intestinal epithelial apicobasal polarity. J Clin Invest. (2014) 124:328-37. doi: 10.1172/JCI71471

110. d'Aldebert E, Quaranta M, Sébert M, Bonnet D, Kirzin S, Portier $\mathrm{G}$, et al. Characterization of human colon organoids from inflammatory bowel disease patients. Front Cell Dev Biol. (2020) 8:363. doi: 10.3389 /fcell.2020.00363

111. Meir M, Salm J, Fey C, Schweinlin M, Kollmann C, Kannapin F, et al. Enteroids generated from patients with severe inflammation in Crohn's 
disease maintain alterations of junctional proteins. J Crohns Colitis. (2020) 14:1473-1487. doi: 10.1093/ecco-jcc/jjaa085

112. Hibiya S, Tsuchiya K, Hayashi R, Fukushima K, Horita N, Watanabe S, et al. Long-term inflammation transforms intestinal epithelial cells of colonic organoids. J Crohns Colitis. (2017) 11:621-30. doi: 10.1093/ecco-jcc/jjw186

113. Verstockt B, Verstockt S, Abdu Rahiman S, Ke B-J, Arnauts K, Cleynen I, et al. Intestinal receptor of SARS-CoV-2 in inflamed IBD tissue seems downregulated by HNF4A in ileum and upregulated by interferon regulating factors in colon. J Crohns Colitis. (2020). doi: 10.1093/ecco-jcc/jjaa185. [Epub ahead of print].

114. Howell KJ, Kraiczy J, Nayak KM, Gasparetto M, Ross A, Lee C, et al. DNA Methylation and transcription patterns in intestinal epithelial cells from pediatric patients with inflammatory bowel diseases differentiate disease subtypes and associate with outcome. Gastroenterology. (2018) 154:585-98. doi: 10.1053/j.gastro.2017.10.007

115. Jardine S, Anderson S, Babcock S, Leung G, Pan J, Dhingani N, et al. Drug screen identifies leflunomide for treatment of inflammatory bowel disease caused by TTC7A deficiency. Gastroenterology. (2020) 158:1000-15. doi: 10.1053/j.gastro.2019.11.019

116. Kim G-A, Spence JR, Takayama S. Bioengineering for intestinal organoid cultures. Curr Opin Biotechnol. (2017) 47:51-8. doi: 10.1016/j.copbio.2017.05.006

117. Fang Y, Eglen RM. Three-dimensional cell cultures in drug discovery and development. SLAS Discov. (2017) 22:456-72. doi: $10.1177 / 1087057117696795$

118. Jin M-Z, Han R-R, Qiu G-Z, Ju X-C, Lou G, Jin W-L. Organoids: an intermediate modeling platform in precision oncology. Cancer Lett. (2018) 414:174-80. doi: 10.1016/j.canlet.2017.11.021

119. Roh TT, Chen Y, Paul HT, Guo C, Kaplan DL. 3D bioengineered tissue model of the large intestine to study inflammatory bowel disease. Biomaterials. (2019) 225:119517. doi: 10.1016/j.biomaterials.2019.119517

120. Bein A, Shin W, Jalili-Firoozinezhad S, Park MH, SontheimerPhelps A, Tovaglieri A, et al. Microfluidic organ-on-a-hip models of human intestine. Cell Mol Gastroenterol Hepatol. (2018) 5:659-68. doi: 10.1016/j.jcmgh.2017.12.010

121. Beaurivage C, Naumovska E, Chang YX, Elstak ED, Nicolas A, Wouters $\mathrm{H}$, et al. Development of a gut-on-A-chip model for high throughput disease modeling and drug discovery. Int J Mol Sci. (2019) 20:5661. doi: 10.3390/ijms20225661

122. Poceviciute R, Ismagilov RF. Human-gut-microbiome on a chip. Nat Biomed Eng. (2019) 3:500-1. doi: 10.1038/s41551-019-0425-0

123. Sidar B, Jenkins BR, Huang S, Spence JR, Walk ST, Wilking JN. Long-term flow through human intestinal organoids with the gut organoid flow chip (GOFlowChip). Lab Chip. (2019) 18:3552-62. doi: 10.1039/C9LC00653B

124. Skardal A, Shupe T, Atala A. Organoid-on-a-chip and body-on-a-chip systems for drug screening and disease modeling. Drug Discov Today. (2016) 21:1399-411. doi: 10.1016/j.drudis.2016.07.003

125. Shin W, Kim HJ. Pathomimetic modeling of human intestinal diseases and underlying host-gut microbiome interactions in a gut-on-a-chip. Methods Cell Biol. (2018) 146:135-48. doi: 10.1016/bs.mcb.2018.05.006

126. Nikolaev M, Mitrofanova O, Broguiere N, Geraldo S, Dutta D, Tabata $\mathrm{Y}$, et al. Homeostatic mini-intestines through scaffold-guided organoid morphogenesis. Nature. (2020) 585:574-8. doi: 10.1038/s41586-020-2724-8

127. Kim HJ, Huh D, Hamilton G, Ingber DE. Human gut-on-a-chip inhabited by microbial flora that experiences intestinal peristalsis-like motions and flow. Lab Chip. (2012) 12:2165-74. doi: 10.1039/c2lc40074j

128. Kim HJ, Lee J, Choi J-H, Bahinski A, Ingber DE. Co-culture of living microbiome with microengineered human intestinal villi in a gut-on-a-chip icrofluidic device. J Vis Exp. (2016) 30:54344. doi: 10.3791/54344

129. Kim HJ, Li H, Collins JJ, Ingber DE. Contributions of microbiome and mechanical deformation to intestinal bacterial overgrowth and inflammation in a human gut-on-a-chip. Proc Natl Acad Sci USA. (2016) 113:E7-15. doi: 10.1073/pnas.1522193112

130. Barrila J, Crabbé A, Yang J, Franco K, Nydam SD, Forsyth RJ, et al. Modeling host-pathogen interactions in the context of the microenvironment: threedimensional cell culture comes of age. Infect Immun. (2018) 86:00282-18. doi: 10.1128/IAI.00282-18

131. Grassart A, Malardé V, Gobaa S, Sartori-Rupp A, Kerns J, Karalis K, et al. Bioengineered human organ-on-chip reveals intestinal microenvironment and mechanical forces impacting shigella infection. Cell Host Microbe. (2019) 26:435-44.e4. doi: 10.1016/j.chom.2019.08.007

132. Jalili-Firoozinezhad S, Gazzaniga FS, Calamari EL, Camacho DM, Fadel $\mathrm{CW}$, Bein A, et al. A complex human gut microbiome cultured in an anaerobic intestine-on-a-chip. Nat Biomed Eng. (2019) 3:520-31. doi: 10.1038/s41551-019-0397-0

133. Lichtenstein GR, Rutgeerts P. Importance of mucosal healing in ulcerative colitis. Inflamm Bowel Dis. (2010) 16:338-46. doi: 10.1002/ibd.20997

134. Bryant RV, Burger DC, Delo J, Walsh AJ, Thomas S, von Herbay A, et al. Beyond endoscopic mucosal healing in UC: histological remission better predicts corticosteroid use and hospitalisation over 6 years of follow-up. Gut. (2016) 65:408-14. doi: 10.1136/gutjnl-2015-309598

135. Colombel JF, Rutgeerts P, Reinisch W, Esser D, Wang Y, Lang Y, et al. Early mucosal healing with infliximab is associated with improved long-term clinical outcomes in ulcerative colitis. Gastroenterology. (2011) 141:1194201. doi: 10.1053 /j.gastro.2011.06.054

136. Rutgeerts P, Diamond RH, Bala M, Olson A, Lichtenstein GR, Bao W, et al. Scheduled maintenance treatment with infliximab is superior to episodic treatment for the healing of mucosal ulceration associated with Crohn's disease. Gastrointest Endosc. (2006) 63:433-42. doi: 10.1016/j.gie.2005.08.011

137. Picco MF, Farraye FA. Targeting mucosal healing in Crohn's disease. Gastroenterol Hepatol. (2019) 15:529-38.

138. Frøslie KF, Jahnsen J, Moum BA, Vatn MH, IBSEN Group. Mucosal healing in inflammatory bowel disease: results from a Norwegian population-based cohort. Gastroenterology. (2007) 133:412-22. doi: 10.1053/j.gastro.2007.05.051

139. Baert F, Moortgat L, Van Assche G, Caenepeel P, Vergauwe P, De Vos $\mathrm{M}$, et al. Mucosal healing predicts sustained clinical remission in patients with early-stage Crohn's disease. Gastroenterology. (2010) 138:463-8. e10-1. doi: 10.1053/j.gastro.2009.09.056

140. Magro F, Gionchetti P, Eliakim R, Ardizzone S, Armuzzi A, Barreirode Acosta M, et al. Third European evidence-based consensus on diagnosis and management of ulcerative colitis. Part 1: definitions, diagnosis, extra-intestinal manifestations, pregnancy, cancer surveillance, surgery, and Ileo-anal pouch disorders. J Crohns Colitis. (2017) 11:649-70. doi: 10.1093/ecco-jcc/jjx008

141. Gomollón F, Dignass A, Annese V, Tilg H, Van Assche G, Lindsay JO, et al. 3rd European evidence-based consensus on the diagnosis and management of Crohn's disease 2016: part 1: diagnosis and medical management. J Crohns Colitis. (2017) 11:3-25. doi: 10.1093/ecco-jcc/jjw168

142. Okamoto R, Shimizu H, Suzuki K, Kawamoto A, Takahashi J, Kawai M, et al. Organoid-based regenerative medicine for inflammatory bowel disease. Regen Ther. (2020) 13:1-6. doi: 10.1016/j.reth.2019.11.004

143. Fukuda M, Mizutani T, Mochizuki W, Matsumoto T, Nozaki K, Sakamaki Y, et al. Small intestinal stem cell identity is maintained with functional Paneth cells in heterotopically grafted epithelium onto the colon. Genes Dev. (2014) 28:1752-7. doi: 10.1101/gad.245233.114

144. Sugimoto S, Ohta Y, Fujii M, Matano M, Shimokawa M, Nanki K, et al. Reconstruction of the human colon epithelium in vivo. Cell Stem Cell. (2018) 22:171-6.e5. doi: 10.1016/j.stem.2017.11.012

145. Meran L, Massie I, Campinoti S, Weston AE, Gaifulina R, Tullie L, et al. Engineering transplantable jejunal mucosal grafts using patient-derived organoids from children with intestinal failure. Nat Med. (2020) 26:1593601. doi: 10.1038/s41591-020-1024-z

146. Fair KL, Colquhoun J, Hannan NRF. Intestinal organoids for modelling intestinal development and disease. Philos Trans R Soc Lond B Biol Sci. (2018) 373:2010217. doi: $10.1098 /$ rstb.2017.0217

Conflict of Interest: The authors declare that the research was conducted in the absence of any commercial or financial relationships that could be construed as a potential conflict of interest.

Copyright $\odot 2021$ O'Connell, Winter and Aherne. This is an open-access article distributed under the terms of the Creative Commons Attribution License (CC BY). The use, distribution or reproduction in other forums is permitted, provided the original author(s) and the copyright owner(s) are credited and that the original publication in this journal is cited, in accordance with accepted academic practice. No use, distribution or reproduction is permitted which does not comply with these terms. 